University of Nebraska - Lincoln

DigitalCommons@University of Nebraska - Lincoln

Biological Systems Engineering: Papers and

Publications

Biological Systems Engineering

1993

\title{
Property Modification of Edible Wheat, Gluten-Based Films
}

\author{
A. Gennadios \\ University of Nebraska-Lincoln, aris.gennadios@catalent.com \\ Curtis L. Weller \\ University of Nebraska-Lincoln, cweller1@unl.edu \\ R. F. Testin \\ Clemson University
}

Follow this and additional works at: https://digitalcommons.unl.edu/biosysengfacpub

Part of the Biological Engineering Commons

Gennadios, A.; Weller, Curtis L.; and Testin, R. F., "Property Modification of Edible Wheat, Gluten-Based Films" (1993). Biological Systems Engineering: Papers and Publications. 90.

https://digitalcommons.unl.edu/biosysengfacpub/90

This Article is brought to you for free and open access by the Biological Systems Engineering at DigitalCommons@University of Nebraska - Lincoln. It has been accepted for inclusion in Biological Systems Engineering: Papers and Publications by an authorized administrator of DigitalCommons@University of Nebraska Lincoln. 


\title{
PROPERTY MODIFICATION OF EdiBle WhEAT, GLUTEN-BASED FILMS
}

\author{
A. Gennadios, C. L. Weller, R. F. Testin \\ Student Member Member \\ ASAE ASAE
}

\begin{abstract}
Procedures were developed to produce edible wheat, gluten-based films. A film was produced as a standard. Five additional films were then produced by modifying the initial film-forming solution. Modifications included changing the plasticizer, partially substituting wheat gluten with soy protein isolate and corn zein, and incorporating two acetylated monoglyceride products. All films were characterized by measuring selected mechanical properties, and permeabilities to water vapor and to oxygen. Comparison of the films, in terms of their measured properties, indicates ways to improve the overall performance of the standard film as a potential packaging material. A main limitation of all of the films was their poor water vapor barrier characteristics. On the other hand, they were very good oxygen barriers. All modified films were stronger than the standard in terms of tensile and bursting strength. The film containing soy protein was the strongest and the most uniform. Significant differences in measured properties were observed when the plasticizer was changed from glycerin to triethylene glycol. Keywords. Edible films, Wheat gluten, Water vapor barriers, Oxygen barriers, Mechanical properties, Physical properties.
\end{abstract}

$\mathrm{F}$ ilms and coatings from edible materials have been suggested for use in food packaging. Such films could mechanically protect foods and retard the rate of food deterioration and spoilage. The concept originated from natural coatings found on numerous horticultural products and other biological materials. Edible films and coatings offer a number of advantages over traditional polymeric packaging materials including the renewable nature of raw materials employed in edible film production; nutritional supplementation and organoleptic enhancement of packaged foods; application in the interior of foods to control intercomponent moisture and solute migration; individual packaging of small food portions and of small-size food products (e.g., beans, peas, and nuts); use as an internal food contact layer in multilayer food packaging materials; and potential for microencapsulation and controlled release of food additives such as preservatives and flavorings (Gennadios and Weller, 1990).

A general classification of edible films and coatings is based on the nature of biopolymers used in film formation and includes polysaccharide, lipid, protein, and composite (made by combining substances from other categories) films (Kester and Fennema, 1986). Several proteins have received attention for their film-forming ability, including gelatin, casein, whey protein, corn zein, wheat gluten, soy protein isolate, serum albumin, and ovalbumin.

Article has been reviewed and approved for publication by the Food and Process Engineering Inst. of ASAE. Presented as ASAE Paper No. 90-6504.

Technical Contribution No. 3164 of the South Carolina Agricultural Experiment Station, Clemson University, Clemson, SC.

The authors are Aristippos Gennadios, Graduate Research Assistant, and Curtis L. Weller, Assistant Professor, Dept. of Biological Systems Engineering, University of Nebraska, Lincoln; and Robert F. Testin, Associate Professor, Dept. of Food Science, Clemson University, Clemson, SC.
Information related to methods and technologies of film development from the aforementioned proteins, as well as qualitative and quantitative characteristics of these films, can be found in recent reviews (Guilbert, 1986, 1988; Kester and Fennema, 1986; Gennadios and Weller, 1990).

Poor performance as water vapor barriers is the main limitation of protein films. This phenomenon is attributed to the hydrophilic (polar) nature of protein film-forming substances. In moist environments, protein films tend to swell (or even dissolve) due to high water sorption rates. As a result, diffusivity of water molecules increases and water vapor transmission (as well as transmission of other gases) through films dramatically increases following nonFickian patterns.

Wheat gluten has not received as much study as other proteins for its film-forming potential. Wall and Beckwith (1969) produced films from commercial and laboratorypurified wheat gluten and from the two fractions of gluten, gliadin and glutenin. In all cases the films were very brittle. Films prepared by combining unmodified and modified polypeptides from wheat gluten hydrolysates exhibited high tensile strength and were practically impermeable to oil, but were readily water soluble (Krull and Inglett, 1971; Gutfreund and Yamauchi, 1974). Okamoto (1978) produced weak films on the surface of heated gluten, gliadin, and glutenin solutions in an alkaline environment. Anker et al. (1972) developed a method to produce strong and flexible films by dispersing wheat gluten in heated alcohol-water alkaline solutions. Aydt et al. (1991) followed the method suggested by Anker et al. (1972) to cast and characterize homogeneous films from wheat gluten. Film testing revealed excellent oxygen and carbon dioxide barrier properties, but poor water vapor barrier properties.

The procedure developed by Aydt et al. (1991) was adapted for the present study, with minor changes, to produce a "standard" film from wheat gluten with glycerin 
as a plasticizer. Five other different films were also cast by modifying the film-forming solution of the standard film. Comparing these films, in terms of selected measured properties, may identify ways to improve the overall performance of the standard film as a potential packaging material (either as a film or as a coating).

\section{OBJECTIVES}

The objectives of this study were to:

- Produce edible films from various wheat glutenbased film-forming solutions.

- Evaluate selected mechanical properties, and oxygen and water vapor barrier characteristics of produced films.

- Compare the measured physical and barrier properties of produced films to those of a standard wheat gluten-based film.

\section{MATERIALS AND METHODS}

Preparation of Film-Forming Solutions

Standard Film. A vital wheat gluten product, DOPEP®, obtained from ADM Arkady (Olathe, KS) was used in this study. This product contains $75 \%$ protein on a dry basis and a maximum of $7.5 \%$ moisture on a wet basis, according to the producer's specifications. A solution of $15 \mathrm{~g}$ gluten in $72 \mathrm{~mL}$ of $95 \%$ ethanol and $6 \mathrm{~g}$ glycerin was prepared. Glycerin was added as a plasticizer. The solution was warmed and stirred on a magnetic stirrer/hot plate, while $48 \mathrm{~mL}$ of distilled water and $12 \mathrm{~mL}$ of $6 \mathrm{~N}$ ammonium hydroxide were slowly added. The mixture was heated on the hot plate until gluten dispersed. This point was easily determined by a significant decrease in solution viscosity. At this stage, the film-forming solution was ready to be cast.

Film No. 1. The $6 \mathrm{~g}$ of glycerin in the original formula were replaced by $5.8 \mathrm{~g}$ of triethylene glycol, another substance with plasticizing effect. On a molecular basis, film No. 1 contained about $40.7 \%$ fewer moles of plasticizer than the standard film. Both glycerin and triethylene glycol are approved by the U.S. Food \& Drug Administration (FDA) as food additives (CFR, 1980).

Film No. 2. Thirty percent on a weight basis of the wheat gluten $(4.5 \mathrm{~g})$ was substituted by soy protein isolate (PP 620®, Protein Technologies International, St. Louis, MO).

Film No. 3. Twenty percent on a weight basis of the wheat gluten ( $3 \mathrm{~g}$ ) was substituted by corn zein, the prolamine protein of corn gluten. Zein was obtained in a powder form (88-96\% protein on a dry basis) from Freeman Industries (Tuckahoe, NY).

Film No. 4. One-half gram of a lipid material, MYVACET® 5-07 (Eastman Chemical Products Inc., Kingsport, TN), a distilled acetylated mono-glyceride product, was added to the standard solution. The number 5 07 in the name of the product denotes approximately $50 \%$ acetylation and an iodine number of seven. The low melting point (about $37^{\circ} \mathrm{C}$ ) of MYVACET ${ }^{\circledR}$ 5-07 simplified its incorporation into the solution. While the solution was heated on the hot plate and before dispersion of gluten took place, the MYVACET ${ }^{\circledR}$ 5-07 was added, melted, and mixed with the solution. The amount of
MYVACET $® 5-07(0.5 \mathrm{~g})$ added was the maximum amount consistent with ensuring that films would peel off the casting surface. Solutions prepared with higher amounts of monoglyceride stuck to the surface upon drying. Distilled acetylated monoglycerides are approved by the FDA as food additives (CFR, 1980).

Film No. 5. One-half gram of another distilled acetylated monoglyceride product, MYVACET® 7-00 (Eastman Chemical Products Inc., Kingsport, TN), was added to the standard solution in a manner similar to that for film No. 4. The MYVACET ${ }^{\circledR}$ 7-00 product had approximately $70 \%$ acetylation, an iodine number equal to zero (thus saturated), and a melting point of about $33^{\circ} \mathrm{C}$. Again $0.5 \mathrm{~g}$ was the maximum amount that could be added, since films from solutions prepared with higher amounts did not peel off the glass after drying.

\section{Casting}

All prepared film-forming solutions, while still warm, were cast on clean, flat glass surfaces. A thin-layer chromatography spreader bar (Brinkman Co., NY) was filled each time with the solution and moved along the glass plate to distribute the solution as evenly as possible. This casting technique provided a limited degree of monoaxial molecular orientation parallel to the direction in which the spreader was moved as opposed to the random orientation of molecules occurring upon pouring and spreading the solution on the substrate surface. Molecular orientation is generally desirable in film production because it improves barrier properties of films (Pascat, 1986). Mixtures for films No. 2 , No. 3 , No. 4 , and No. 5 were passed through a hand homogenizer (Chase-Logeman Co., Hicksville, NY) before being cast with the spreader.

\section{DRYING}

Cast films were dried for $15 \mathrm{~h}$ in an air-circulating oven (Isotemp®, Model 338F, Fisher Scientific, Pittsburgh, PA) set at $32 \pm 2^{\circ} \mathrm{C}$. At the end of the drying period, films were peeled off the glass surface.

\section{Conditioning}

Film specimens used in testing of mechanical properties were conditioned for $48 \mathrm{~h}$ immediately prior to testing in a desiccator maintained at a relative humidity $(\mathrm{RH})$ of $50 \pm 5 \%$ and a temperature of $23 \pm 2^{\circ} \mathrm{C}$ (ASTM Standard Method D 618-61, ASTM, 1989). RH in the desiccator was provided by a saturated calcium nitrate solution. Film specimen conditioning before testing for oxygen gas and water vapor transmission rates was conducted in a desiccator at $11 \pm 5 \% \mathrm{RH}$ and $23 \pm 2^{\circ} \mathrm{C}$ for $48 \mathrm{~h}$ prior to testing. $\mathrm{RH}$ in the desiccator was maintained by a saturated solution of lithium chloride.

\section{THICKNESS}

A TMI Series "400" Micrometer Model 49-60 (Amityville, NY) was used to determine film thickness to the nearest $0.254 \mu \mathrm{m}(0.01 \mathrm{mil})$. For each type of film, four different sheets were cast and from each sheet three samples, $5 \mathrm{~cm} \times 5 \mathrm{~cm}$ in size, were taken to measure thickness. From every $5 \mathrm{~cm} \times 5 \mathrm{~cm}$ sample, five micrometer readings at different points were recorded, thus yielding a total of 60 thickness observations for each film type. 


\section{Bursting STRENGTH}

A Mullen Burst Tester (TMI Co., Amityville, NY) was used to measure bursting strength of films to the nearest $1.72 \mathrm{kPa}(0.25 \mathrm{psi})$ in accordance with ASTM Standard Method D 774-87 (ASTM, 1989). Samples $7.6 \mathrm{~cm} \times 7.6 \mathrm{~cm}$ in area were placed between the clamping plates of the tester and ruptured by the diaphragm. For every type of film, three specimens were obtained and measured from each one of four different prepared sheets (a total of 12 observations for each film type).

\section{Propagation Tear Resistance}

An Elmendorf Tear Tester (TMI Co., Amityville, NY) was used to measure propagation tear resistance of films to the nearest $0.16 \mathrm{~g}$ according to the pendulum method described in ASTM Standard Method D 1922-67 (ASTM, 1989). Tested specimens were rectangular in shape, $76 \mathrm{~mm} \times 63 \mathrm{~mm}$. The $63 \mathrm{~mm}$ dimension was the dimension of tear. Maximum capacity of the pendulum on the Elmendorf Tear Tester was $16 \mathrm{~g}$. From each of four different sheets cast of each type of film, three specimens were tested, making a total of 12 specimens for every type of film.

\section{Tensile Strength and Percentage Elongation at BREAK}

An Instron Universal Testing Instrument (Model 4201, Instron Engineering Corp., Canton, MA) was used to determine film tensile strength and percentage elongation at break. Testing was performed using Test Method A (Static Weighing-Constant-Rate-of-Grip Separation) described in ASTM Standard Method D 882-88 (ASTM, 1989). Initial grip separation and cross-head speed were set at $50 \mathrm{~mm}$ and $500 \mathrm{~mm} / \mathrm{min}$, respectively. Tensile strength was calculated by dividing the maximum (peak) load (measured to the nearest $0.000981 \mathrm{~N}$ ) necessary to pull the specimen apart by the cross-sectional area of the specimen. Average thickness of the sheet from which a specimen was taken, was used to estimate the cross-sectional area of the specimen. Percentage elongation at break was calculated by dividing film elongation at the moment of rupture (measured to the nearest $0.1 \mathrm{~mm}$ ) by $50 \mathrm{~mm}$ (initial gage length of specimens) and multiplying by $100 \%$. Tested specimens were rectangular strips $100 \mathrm{~mm}$ in length and $25.4 \mathrm{~mm}$ in width. For each type of film, 12 specimens were measured, three from each of four separately produced sheets.

\section{Water Vapor Permeability}

A computer monitored, six-station water vapor transmission instrument (PERMATRAN-W600, Mocon Inc., Minneapolis, MN) was used to measure water vapor transmission of films. This system was operated according to ASTM Standard Method F 1249-89 (ASTM, 1989). One station was loaded with a reference (calibration) film (polyester $0.92 \mathrm{mils}$ ) in order to verify proper operation of the system and the other five stations were loaded with test samples for measurement. Film samples $10 \mathrm{~cm} \times 10 \mathrm{~cm}$ were mounted between the two halves of the testing cells which had an internal surface area of $50 \mathrm{~cm}^{2}$. Two absorbent pads, moistened with saturated lithium chloride (LiCl) solution, were placed in the lower half of the cells. The upper cell halves were vented with dry nitrogen gas which functions as a carrier gas for transmitted water vapor. Nitrogen flow was kept constant at $593.8 \mathrm{~cm}^{3} / \mathrm{min}$.

The driving force for water vapor transmission through the films is the difference between relative humidities $(\mathrm{RH})$ or more accurately, the difference between partial water vapor pressures on the two sides of the films. One side of film samples was exposed to the saturated $\mathrm{LiCl}$ solution and the other to the dry environment of the flowing nitrogen (0\% RH). Testing was performed at $23^{\circ} \mathrm{C}$ and at this temperature the $\mathrm{RH}$ over saturated $\mathrm{LiCl}$ solution is $11.1 \%$ (Greenspan, 1977). The desired temperature of $23^{\circ} \mathrm{C}$ was maintained by a water bath attached to the test machine.

After loading samples in the cells, a period of conditioning allowed the samples to approach equilibrium. Specifically the specimens were exposed to nitrogen purging for about $16 \mathrm{~h}$. Testing started by venting the nitrogen with transmitted water vapors to a pressuremodulated infrared sensor for measurement of water vapor transmission rates (WVTR). Accuracy of measurement was $0.1 \mathrm{~g} / \mathrm{m}^{2} /$ day. The machine monitored one cell at a time for a period of $15 \mathrm{~min}$ (dwell time), before moving to the next one. Testing for each cell was automatically terminated when recorded measurements differed from each other by less than $1 \%$ after a $1 \mathrm{~h}$ period. This was an indication that WVTR through the samples had reached steady state.

Films were subjected to a small partial water vapor pressure gradient, to reduce the amount of vapors transmitted and carried to the sensor. Protein films, in general, are poor water barriers (high transmitters) and testing with higher driving forces would have resulted in: (1) saturation, overrange, and possible damage to the sensor, and (2) swelling and plasticization of films leading to non-Fickian behavior. The amount of water vapor passed through samples was further reduced by a factor of 10 , by masking specimens with precut aluminum foil masks to leave an uncovered film area of only $5 \mathrm{~cm}^{2}$. Masking also provided mechanical support to specimens, making them easier to handle. Furthermore, limiting the effective area of films available for water vapor transmission resulted in samples of more uniform thickness.

The ratio of WVTR for each sample to the difference in partial pressures of water vapor on the two sides of a film sample defines permeance. At the operating temperature of $23^{\circ} \mathrm{C}$, partial pressure of saturated water vapor is 2808.36 Pa (Felder and Rousseau, 1978). Partial water vapor pressures on the two sides of film samples were: $0.111 \times 2808.36 \mathrm{~Pa}=311.73 \mathrm{~Pa}$ on the side facing the $11.1 \% \mathrm{RH}$ environment and zero on the side facing the nitrogen environment. So the difference in partial water vapor pressure was $311.73 \mathrm{~Pa}$. Multiplying the permeance by the thickness of a sample yields permeability. Thickness of samples necessary to calculate permeability was determined as an average of five measurements taken from the $5 \mathrm{~cm}^{2}$ effective area of an individual sample. In total four samples from each type of film were measured with individual samples taken from separately cast sheets.

\section{Oxygen Gas Permeability}

An OX-TRAN 1000 instrument (Mocon Inc., Minneapolis, MN), that operates according to ASTM Standard Method D 3985-81 (ASTM, 1989), was used to 
Table 1. Selected mechanical properties of various wheat gluten-based films*

\begin{tabular}{|c|c|c|c|c|c|}
\hline Type of Film & $\begin{array}{c}\text { Thickness } \\
(\mu \mathrm{m})\end{array}$ & $\begin{array}{c}\text { Propagation } \\
\text { Tear } \\
\text { Resistance (g) }\end{array}$ & $\begin{array}{c}\text { Bursting } \\
\text { Strength (kPa) }\end{array}$ & $\begin{array}{c}\text { Tensile } \\
\text { Strength (MPa) }\end{array}$ & $\begin{array}{c}\text { Elongation } \\
\text { at } \\
\text { Break }(\%)\end{array}$ \\
\hline $\begin{array}{l}\text { Wheat/ Glycerin (STD) } \\
\text { Wheat / Triethylene }\end{array}$ & $101 \pm 23 \mathrm{a}$ & $4.1 \pm 0.8 \mathrm{a}$ & $74.7 \pm 5.3 \mathrm{~b}$ & $2.6 \pm 0.2 \mathrm{~d}$ & $276.2 \pm 28.7$ a \\
\hline $\begin{array}{l}\text { Glycol (No. 1) } \\
\text { Wheat / Soy (No. 2) } \\
\text { Wheat / Zein (No. 3) } \\
\text { Wheat / MYVACET }{ }^{\circledR}\end{array}$ & 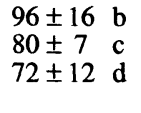 & $\begin{array}{l}2.6 \pm 0.6 \mathrm{~b} \\
1.8 \pm 0.2 \mathrm{c} \\
1.4 \pm 0.3 \mathrm{~d}\end{array}$ & $\begin{array}{l}83.0 \pm 5.2 \mathrm{a} \\
85.5 \pm 4.2 \mathrm{a} \\
77.7 \pm 3.8 \mathrm{~b}\end{array}$ & $\begin{array}{l}3.8 \pm 0.3 \mathrm{bc} \\
4.4 \pm 0.5 \mathrm{a} \\
4.1 \pm 0.5 \mathrm{ab}\end{array}$ & $\begin{array}{l}185.9 \pm 24.6 \mathrm{c} \\
233.3 \pm 23.0 \mathrm{~b} \\
174.7 \pm 52.8 \mathrm{c}\end{array}$ \\
\hline $\begin{array}{l}\text { 5-07 (No. 4) } \\
\text { Wheat / MYVACET® }\end{array}$ & $66 \pm 13 \mathrm{e}$ & $2.1 \pm 0.5 \mathrm{c}$ & $75.9 \pm 5.4 \mathrm{~b}$ & $3.7 \pm 0.4 \mathrm{c}$ & $254.1 \pm 37.0 \mathrm{ab}$ \\
\hline 7-00 (No. 5) & $64 \pm 9 \mathrm{e}$ & $1.8 \pm 0.6 \mathrm{c}$ & $77.0 \pm 5.3 \mathrm{~b}$ & $4.1 \pm 0.6 \mathrm{ab}$ & $262.2 \pm 43.4 \mathrm{ab}$ \\
\hline
\end{tabular}

ickness and 12 replicates for all other properties \pm one $(P<0.05)$ according to Duncan's New Multiple-Range Test.

measure oxygen gas transmission rate (OGTR) of films to the nearest $0.01 \mathrm{~cm}^{3} / \mathrm{m}^{2}$.day. This is a computer monitored, ten-station instrument equipped with a coulometric oxygen sensor. Two of the testing stations (cells) were loaded with reference (calibration) films (polyester 0.92 mils and polyester 5 mils) during each test, in order to verify the validity of test measurements. The other eight stations were loaded with film samples.

Film samples $(10 \mathrm{~cm} \times 10 \mathrm{~cm})$ were masked with precut aluminum foil masks $\left(5 \mathrm{~cm}^{2}\right.$ uncovered area) and clamped in the testing cells. Mechanical support and also a smaller and, therefore, more uniform area of thickness were the objectives of masking. Testing was conducted in a dry environment (0\% RH) since the glass bubblers on the instrument through which nitrogen and oxygen gases pass were not filled with water. Temperature during testing was maintained constant at $23^{\circ} \mathrm{C}$ with the aid of an attached cooling unit. Prior to OGTR measurement, samples were conditioned in the machine for about $16 \mathrm{~h}$ by flushing both halves of the cells with $\mathrm{N}_{2}$.

Concentrations of oxygen detected by the sensor were due to oxygen transmitted through the samples, but also to oxygen admitted to the sensor through system leaks. Since the films proved to be very effective oxygen barriers (low transmitters), leak contributions were given consideration. Leak rates were measured and recorded, before testing with oxygen, by purging nitrogen on the top of the cells. Then the test gas was changed from nitrogen to oxygen prior to testing. Leak rates for each sample were subtracted from the final observed OGTR. During testing, flow rate of oxygen was set at $150 \mathrm{cc} / \mathrm{min}$. Flow rate of nitrogen through the sensor was set at $14 \mathrm{cc} / \mathrm{min}$ and through each station at $5 \mathrm{cc} / \mathrm{min}$. Testing time for each cell in a test cycle (dwell time) was $15 \mathrm{~min}$. Testing was stopped automatically for each cell when the OGTR changed less than $1 \%$ in a $1-\mathrm{h}$ period, indicating that samples had reached an equilibrium state.

Oxygen gas permeability (OGP) values were calculated from OGTR data in a manner similar to the calculation of WVP values. The difference in oxygen partial pressure across the two sides of film samples was assumed to be $101308 \mathrm{~Pa}(1 \mathrm{~atm})$, since pure oxygen was purged through tested films. Thickness was determined as an average of five thickness measurements made on the effective $5 \mathrm{~cm}^{2}$ sample area with the TMI Micrometer. For each type of film, the OGP value of four samples was determined, with each sample cut from a separately produced sheet.

\section{RESUlTS AND Discussion}

Results obtained for selected mechanical properties, namely thickness, propagation tear resistance, bursting strength, tensile strength, and percentage elongation at break, are presented in table 1 . Water vapor and oxygen gas permeability values are shown in table 2 . Within each property, calculated mean values were compared using Duncan's New Multiple-Range Test (Steel and Torrie, 1980 ) at the $\alpha=0.05$ level of significance.

\section{Mechanical Properties}

Film thickness is of importance, since it is used in calculation of several other property values and it affects the magnitude and comparability of measurements obtained for other properties. Observed thickness differences among prepared films were due to differences in viscosity of film-forming solutions. Movement of the latter, when cast on glass plates, was not restrained. Therefore, spreading of solutions on glass surfaces occurred in an extent determined by their viscosity.

All alternative film-forming solutions yielded thinner films than the standard film (table 1). Lack of thickness uniformity among films of the same type, as well as within individual sheets, was attributed to two factors: (1) shelves of the oven, where cast films were placed for drying, were not totally level thus causing settling toward the lower section during drying and (2) casting of films with the thinlayer spreader bar was performed manually and thus velocity of the spreader, while moving on the glass plates, varied.

Table 2. Water vapor permeability (WVP) and oxygen gas permeability (OGP) of various wheat gluten-based films*

\begin{tabular}{|c|c|c|}
\hline Type of Film & $\begin{array}{c}\text { WVP } \dagger \times 10^{-11} \\
(\mathrm{~g} / \mathrm{m} \cdot \mathrm{s} \cdot \mathrm{Pa})\end{array}$ & $\begin{array}{c}\text { OGP } \ddagger \\
(\mathrm{amol} / \mathrm{m} \cdot \mathrm{s} \cdot \mathrm{Pa}\end{array}$ \\
\hline $\begin{array}{l}\text { Wheat/Glycerin (STD) } \\
\text { Wheat/Triethylene Glycol (No. 1) } \\
\text { Wheat/Soy (No. 2) } \\
\text { Wheat/Zein (No. 3) } \\
\text { Wheat/MYVACET } ₫ 5 \text {-07 (No. 4) } \\
\text { Wheat/MYVACET®-00 (No. 5) }\end{array}$ & $\begin{array}{l}5.6 \pm 0.3 \mathrm{c} \\
9.0 \pm 0.6 \mathrm{a} \\
5.1 \pm 0.4 \mathrm{~cd} \\
4.3 \pm 1.0 \mathrm{~d} \\
5.6 \pm 0.3 \mathrm{c} \\
6.6 \pm 0.5 \mathrm{~b}\end{array}$ & $\begin{array}{ll}2.0 \pm 0.2 & b \\
15.4 \pm 3.0 & \mathrm{a} \\
1.2 \pm 0.1 & \mathrm{~b} \\
2.1 \pm 0.6 & \mathrm{~b} \\
1.4 \pm 0.2 & \mathrm{~b} \\
2.1 \pm 0.4 & \mathrm{~b}\end{array}$ \\
\hline
\end{tabular}

* Reported values are means of four replicates \pm one standard deviation. Any two means followed by the same small case letter are not significantly different $(\mathrm{P}<0.05)$ according to Duncan's New Multiple-Range Test.

$\dagger$ Water vapor permeability values were evaluated at $23^{\circ} \mathrm{C}$ with $11.1 \% \mathrm{RH}$ on one side of the films and $0 \% \mathrm{RH}$ on the other.

$\ddagger$ Oxygen gas permeability values were evaluated at $23^{\circ} \mathrm{C}$ and $0 \% \mathrm{RH}$, where $1 \mathrm{amol}=10^{-18} \mathrm{~mol}$. 
Propagation tear resistance is defined as the average force in grams per film specimen required to propagate tearing through a specified length. This property estimates tearing resistance of films during actual packaging. Generally, there is not a linear relationship between tear resistance and thickness of films. Therefore, direct comparison of tear resistance data is meaningful only for films of similar thickness. In this study, differences among mean thicknesses of films were judged statistically significant $(\mathrm{P}<0.05)$. Consequently, gathered propagation tear resistance data (table 1) and comparisons among them should be viewed as revealing tendencies rather than as absolute indications.

Bursting strength of a film is defined as the hydrostatic pressure required to burst the film and characterizes films in terms of their resistance to rupture. Standard film and films No. 3, No. 4, and No. 5 had lower bursting strength than films No. 1 and No. 2 (table 1).

Tensile strength expresses the maximum stress developed in a film during a tensile test and offers a measure of integrity and heavy-duty use potential for films. In comparison with the standard film, all other films yielded significantly greater $(P<0.05)$ tensile strength values (table 1). The strongest among them, the film containing soy isolate (film No. 2), had an average tensile strength about $69 \%$ higher than the standard film.

Percentage elongation at break is a quantitative representation of a film's ability to stretch (extend). This property is very closely associated with the degree of plasticization induced during film production. Usually elongation at break and tensile strength of a film are inversely related. Films with higher elongation values, require smaller applied loads to break under tensile testing. This was true for the standard film since it was found to have the greatest elongation at break and the lowest tensile strength (table 1).

\section{Barrier Properties}

High water vapor permeability remains the greatest limitation of protein films when considering commercial packaging applications. Values obtained in this study were not very high, but conditions at which testing was performed $\left(23^{\circ} \mathrm{C}\right.$ and $11.1 \% \mathrm{RH}$ gradient) impacted this result. Usually commercial polymeric films are tested for water vapor permeability at $38^{\circ} \mathrm{C}$ and a $90 \% \mathrm{RH}$ gradient. Lower values used in this study were selected to prevent saturation of the testing instrument.

The film containing corn zein (film No. 3) was the only one with a significantly better water vapor barrier characteristic than the standard film by about $23 \%$ (table 2). Variability among measurements for this specific film, though, were high (CV 22\%).

In contrast with water vapor, films produced in this study were very good oxygen gas barriers. Packaging films are considered as high barriers to oxygen when their OGTR is less than $5 \mathrm{cc} / \mathrm{m}^{2}$.day. Testing of the wheat gluten-based films gave OGTR values at that level, with the exception of the wheat gluten/triethylene glycol film (No. 1). If a comparison is made by leaving out film No. 1, then the wheat/soy (film No. 2) and the wheat/MYVACET ${ }^{\circledR}$ 5-07 (film No. 4) would have significantly lower oxygen permeabilities than the other films. Films No. 2 and No. 4 had a mean value about $40 \%$ and $30 \%$, respectively, lower than the standard film.

\section{Film Characteristics}

Plasticizers are added to films in order to "soften" their structure and increase their flexibility. They act by decreasing the accumulation of intermolecular forces along polymer chains (Mellan, 1961). Generally, an increase in the amount of added plasticizer results in lower tensile and bursting strength, but, on the other hand, in higher elongation. Water and gas barrier characteristics of films appear to be affected negatively by plasticizers. Since plasticizers reduce the rigidity of polymer structure, diffusion of permeants through the films is easier.

Film No. 1 was made by adding triethylene glycol instead of glycerin, as a plasticizer and it contained, on a molecular basis, about $40.7 \%$ less plasticizer than the standard film. It was found to have higher tensile and bursting strength, along with smaller elongation than the standard film. Its barrier properties, though, were significantly inferior. This may be attributed to the larger molecule size of triethylene glycol in comparison with glycerin. Plasticizer and polymer, generally, are theorized to form a complex with the aid of secondary valence forces (Mellan, 1961). Triethylene glycol molecules, being fewer but larger than glycerin molecules, may have created wider openings when intermixed with protein macromolecules. Another possible explanation could be the larger number of polar hydroxyl groups contained in glycerin. Glycerin molecules contain three hydroxyl groups while triethylene glycol molecules contain two. Polar groups in plasticizers are believed to develop polymer-plasticizer bonds replacing the polymer-polymer secondary bonds (Arnold, 1968). Therefore, glycerin is expected to provide more bonding with the gluten molecular chains, resulting in greater cross-linking and barrier ability than with the use of triethylene glycol.

Other plasticizers, approved by the FDA as food additives, were also investigated during the present study and all yielded brittle and flaky films, inferior to films plasticized with glycerin and triethylene glycol. These plasticizing substances were ethyl phthalate, tributyl citrate, and three different polyethylene glycols (molecular weight: 400,4000 , and 6000). Such observations indicate the importance of plasticizer selection in film production from protein and possibly from other edible materials.

Film No. 2, produced by substituting $30 \%$ wheat gluten with soy isolate, had the lowest oxygen permeability, and the highest tensile and bursting strengths. Also its elongation at break and its water vapor permeability were approximately the same as the standard film. An interesting observation was that film No. 2 had either the smallest or among the smallest variabilities for every measured property. This indicated higher uniformity and homogeneity of film No. 2 in comparison with all other films.

Film No. 3, produced by substituting $20 \%$ of the wheat gluten with corn zein, was found to have the lowest water vapor permeability. This was not unexpected. Aydt et al. (1991) measured water vapor permeability (at $26^{\circ} \mathrm{C}$ and $50 \% \mathrm{RH}$ gradient) for a wheat gluten film, similar to the standard one in this study, as well as a film made totally from corn zein. They concluded that the corn zein film was 
three times better as a water vapor barrier than the wheat gluten-based one. Supporting this, Guilbert (1986 and 1988) qualitatively characterized corn zein films as "good" water barriers, while he characterized other protein films, produced from gelatin, casein, serum albumin, ovalbumin, and soy isolate, as "poor" water barriers.

In terms of the mechanical properties, film No. 3 had higher tensile strength than the standard film, but, conversely, it had the lowest elongation at break and propagation tear resistance among all films. Film No. 3 was also slightly different in color. In contrast with the translucent cream color of the other films, it had a yellowish appearance due to the corn zein.

Two lipid products, MYVACET ${ }^{\circledR}$ 5-07 and MYVACET ${ }^{\circledR}$ 7-00, were added during preparation of films No. 4 and No. 5, respectively, in order to take advantage of their hydrophobic (non-polar) nature and reduce water vapor permeability of the standard film. No improvement was noticed though, probably due to the small amount of lipids (up to $3.33 \%$ of the wheat gluten on a weight basis) incorporated in the film-forming solutions. Both films No. 4 and No. 5 had higher tensile strength than the standard, while their elongation was at the same level with the latter.

\section{CONCLUSIONS}

Conclusions obtained from this study were:

1. Production of edible films from cast wheat glutenbased film-forming solutions was consistent enough to allow for measurement of selected mechanical and barrier film properties.

2. Wheat gluten-based films had high water vapor permeabilities $(4.3-9.0 \mathrm{~g} / \mathrm{m} \cdot \mathrm{s} \cdot \mathrm{Pa})$ and this remains the major limitation when considering potential commercial application.

3. Oxygen permeability values of wheat gluten-based films were very low $(1.2-15.4 \mathrm{amol} / \mathrm{m} \cdot \mathrm{s} \cdot \mathrm{Pa})$.

4. Films produced with incorporation of acetylated monoglycerides did not have significantly $(\mathrm{P}<0.05)$ lower water vapor permeability than the standard film.

5. All modified films had significantly $(\mathrm{P}<0.05)$ higher tensile strength (by about 42-69\%) than the standard film.

6. A film made from wheat gluten and corn zein in a 4:1 ratio (weight basis) had significantly $(\mathrm{P}<0.05)$ lower water vapor permeability (by about $23 \%$ ) than the standard.

7. A film made from wheat gluten and soy protein isolate in a 2.3:1 ratio (weight basis) had significantly $(\mathrm{P}<0.05)$ lower oxygen permeability (by about $40 \%$ ) than the standard film.
ACKNOWLedgment. This research was supported by a South Carolina Agricultural Experiment Station Enhancement in Packaging Research Competitive Grant.

\section{REFERENCES}

Anker, C. A., G. A. Foster and M. A. Loader. 1972. Method of preparing gluten containing films and coatings. U.S. Patent No. $3,653,925$.

Arnold, L. K. 1968. Introduction to Plastics. Ames, IA: Iowa State University Press.

ASTM. 1989. Annual Book of ASTM Standards. Philadelphia, PA: American Society for Testing and Materials.

Aydt, T. P., C. L. Weller and R. F. Testin. 1991. Mechanical and barrier properties of edible corn and wheat protein films. Transactions of the ASAE 34(1):207-211.

Code of Federal Regulations (CFR). 1980. Title 21: Foods and Drugs, Parts 170-199. Washington, DC: GPO.

Felder, R. M. and R. W. Rousseau. 1978. Elementary Principles of Chemical Processes. New York: John Wiley \& Sons, Inc.

Gennadios, A. and C. L. Weller. 1990. Edible films and coatings from wheat and corn proteins. Food Technol. 44(10):63-69.

Greenspan, L. 1977. Humidity fixed points of binary saturated aqueous solutions. J. Res. Nat. Bur. Stand. (U.S.) 81 A(1):8996.

Guilbert, S. 1986. Technology and application of edible protective films. In Food Packaging and Preservation. Theory and Practice, ed. M. Mathlouthi, 371-394. London, England: Elsevier Appl. Science Pub. Co.

Guilbert, S. 1988. Use of superficial edible layer to protect intermediate moisture foods: Application to the protection of tropical fruit dehydrated by osmosis. In Food Preservation by Moisture Control, ed. C. C. Seow, 199-219. London, England: Elsevier Appl. Science Pub. Co.

Gutfreund, K. and T. Yamauchi. 1974. Potentially useful products derived from gluten hydrolyzate. In Proc. 8th National Conference on Wheat Utilization Research, ed. D. A. Fellers, 32-38. Albany, CA: USDA.

Kester, J. J. and O. R. Fennema. 1986. Edible films and coatings: A review. Food Technol. 40(12):47-59.

Krull, L. H. and G. E. Inglett. 1971. Industrial uses of gluten. Cereal Sci. Today 16(8):232-236, 261.

Mellan, I. 1961. The Behavior of Plasticizers. New York: Pergamon Press.

Okamoto, S. 1978. Factors affecting protein film formation. Cereal Foods World 23(5):256-262.

Pascat, B. 1986. Study of some factors affecting permeability. In Food Packaging and Preservation. Theory and Practice, ed. M. Mathlouthi, 7-24. London, England: Elsevier Appl. Science Pub. Co.

Steel, R. G. D. and J. H. Torrie. 1980. Principles and Procedures of Statistics. A Biometrical Approach, 2nd Ed. New York: McGraw-Hill.

Wall, J. S. and A. C. Beckwith. 1969. Relationship between structure and rheological properties of gluten proteins. Cereal Sci. Today 14(1):16-18, 20-21. 